\title{
Empirical Analysis on Non-Performing Loans of Listed Banks in Vietnam
}

\author{
Thi Thanh Binh Dao* Trinh Thu Huong Phan \\ Hanoi University, Faculty of Management and Tourism, Km 9 Nguyen Trai, Thanh Xuan District, Hanoi
}

\begin{abstract}
Non-performing loans has always been a serious concern for the banking system in Vietnam over the years, especially after the financial crisis year 2008. The huge volume of non-performing loans may lead to severe consequences for the whole economy at both macroeconomic and microeconomic level. The determinants of the NPLs problems are identified by building up models that explain non-performing loans by macroeconomic factors and bank-specific factors which are adjusted from the earlier studies to fit with the context in Vietnam. In short, the level of NPLs is primarily contributed by bank-specific factors. Also, it is recommended that banks should improve lending policies to prevent the increase in non-performing loans. Last but not least, it is urgent for the State Bank of Vietnam in general and banks themselves in particular to conduct a strict procedure in implementation, control, management, and supervision of all activities in order to carry out solutions in time before the problems are getting worse.
\end{abstract}

Keywords: NPLs, macroeconomic, banks

DOI: $10.7176 / \mathrm{EJBM} / 12-6-03$

Publication date: February $29^{\text {th }} 2020$

\section{Introduction}

It is undeniable that banks play an important role in the economy system of each country across the globe, especially in Vietnam, where more than 100 banks are operating according to figure from State Bank of Vietnam in year-end 2018. Besides, credit risk is always extremely important to banking industry since its core business is formed by lending operations. Credit risk or default risk depends on the quality of assets, and it is reflected through the volume of non-performing loans (NPLs). Various researches and literatures have showed that both emerging and matured economies have to deal with a significant increase in problem of NPLs. In the past, Vietnam also used to confront with severe issue related to NPLs which raised serious threats to the whole economy, especially the financial crisis in 2008, and it still remains a big concern these days. Hence, it is essential to determine the factors causing NPLs and develop an effective resolution for the overall banking industry in general, and listed banking sector in particular.

With the purpose of identify the determinants related to NPLs in banking sector in Vietnam, this paper concentrates on establishing a quantitative model that can explain the NPLs level by using macroeconomic and bank-specific factors. It and then provides some recommendations to improve the situation, reducing the increase in NPLs level and avoiding bad debt crisis. The research consists of six sections: Introduction, Banking situation, Literature review, Research methodology, Data analysis, results and discussions, and Summary, conclusion and recommendations.

As stated above, NPLs and listed banks not only is closely related to each other but they also have an important role in the economy in Vietnam. Therefore, it raises some questions as follows: What are the determinants of NPLs in listed banking sector in Vietnam? What recommendations for banks is driven from this model to prevent the increase in NPLs level and avoid bad debt crisis?

This research seeks to determine the effects of macroeconomic and bank-specific factors on non- performing loan of listed banking sector in Vietnam's Stock Exchange.

The major beneficiaries of this research are: the banks' management, the credit ratings institutions, and the external stakeholders who are interested in knowledge of NPLs level of listed banking sector in Vietnam. The findings are to help managers and directors of banks in identifying causes and predicting trends of NPLs in their bank itself and in the whole country. It also assists in understanding the role of NPLs and listed banks in the economy. Moreover, the research aids in making decision on lending procedure and provisioning policy to lower NPLs and reduce related losses, as well as ensure best quality loans are extended.

The paper organizes as follows: the first section, Introduction, will present an overview about NPLs and listed banking sectors situations in Vietnam, as well as research questions and its contribution. Section 2 reviews some theoretical frameworks and different qualitative and recommendations for the banks, as well as points out the limitation of this research.

\section{International banking standard Basel}

Basel Accords are a set of international banking regulations put forth by the Basel Committee on Bank Supervision (BCBS) that provides recommendations on banking regulations in regards to capital risk, market risk, and 
operational risk. The purpose of the accords is to ensure that financial institutions have enough capital on account to meet obligations and absorb unexpected losses.

The reason why Capital Adequacy Ratio is critical is because CAR make sure banks have enough cushion to absorb a reasonable amount of losses before they become insolvent and consequently lose depositors' funds, thus it ensures the efficiency and stability of financial system by reducing the insolvent risk of bank. Therefore, a bank with a high capital adequacy ratio is considered safe and likely to meet its financial obligations.

State Bank of Vietnam has issued some regulations about capital adequacy ratio. Some of them are Circular 13/2010/TT-NHNN on May 20, 2010, Circular 36/2014/TT-NHNN on November 20, 2014, and Circular $36 / 2014 /$ TT-NHNN on November 20, 2014. The most recent one is Circular 41/2016/TT-NHNN which adjust CAR from $9 \%$ to $8 \%$ but supplementing other capital requirements. This Circular will take effect from January 1 , 2020.

Basel II is the second international banking regulatory accord issued by BCBS in 2004 with the aim of overcome shortcomings of Basel I by making capital requirements more risk sensitive. In fact, Basel I primary focused on credit risk, while Basel II includes three major components of risk that a bank faces: credit risk, operational risk and market risk. The framework of Basel I contains three pillars: (i) minimum capital requirements (Pillar 1); (ii) Supervisory review process (Pillar 2); and (iii) Market Discipline (Pillar 3).

\section{Literature review on determinants of NPLs \\ 3.1 Theoretical Framework}

Although there is not specific theory which properly presents about NPLs, this section of literature reviews covers the theories that is most likely to relate to the research question and explain concept as well as the components affecting NPLs of banks. There are four appropriate theories, which are the Stakeholder theory, Risk Management theory, Adverse Selection theory, and Moral Hazard theory.

\section{Stakeholder theory and Risk Management theory}

A stakeholder approach to strategy emerged in the mid-1980's and its focal point was the Stakeholder theory, first proposed by Freeman (1984). The Stakeholder theory focuses on equilibrium of both moral and ethical values in the management of a business or other organization, which suggests that a company's real success comes from satisfying all its stakeholders including just about anyone affected by the company and its operation (Kubai, 2016). Loosemore and Phua (2010) also states that the theory is largely involved in the risk management decision-making processes, and thus provides diversified feasible rationale for risk management such as bad debt.

Meanwhile, it is often argued that performance is linked to the firm's default risk (Shapiro and Titman, 1986) and the risk management function within the organization would be responsible for the direct management of the risk management policy of the entity, which causes high loan default (Spikin, 2013), and to some extent, affects the bad debt ratio.

The Stakeholder theory and Risk Management theory is closely relevant to the research because it highlights the relationship between organization's performance and NPLs through stakeholders and daily activities.

\section{Adverse Selection theory}

According to Lambert et al., (2011), the theory of asymmetric information explains how it is difficult to distinguish between good or bad borrowers and thus results in adverse selection and moral hazards issues. The theory refers generally to a situation of unequal knowledge (information failure) in which a party possesses more information on specific item to be transacted than the other party, leading to a more favorable position for negotiation. The party with less information is consequently likely to make either right or wrong decision related to the transaction (Auronen, 2003). Therefore, adverse selection is one of the reasons leading to considerable growth in bad debt for banks (Bofondi and Gobbi, 2003).

This theory is relevant to the research as it exposes the primary cause of NPLs. In this case, both parties, the lender and the borrower possibly play the role of either the more-information side or the less-information side. Banks can charge interest rates that are unfavorable to borrowers and borrowers can also conceal their information and leave banks with a subprime loan, which increases the default risk and contributes to the bad debt ratio.

\section{Moral Hazard theory}

Moral Hazard theory and Adverse Selection theory are both based on the theory of asymmetric information (incomplete information). However, the Moral Hazard is more about an ethical issue in which a party has an incentive to take risks without taking responsibility when entering into a transaction. They may provide misleading information or change their behavior because they believe they will avoid any consequences arising from their actions (Holmstrom, 1982). Both Jensen and Meckling (1976) and Cincinelli (2017) implicitly suggests that moral hazard problems within banking sector result in a higher loan growth rate and a larger number of NPLs. A typical example is the financial crisis in 2008, when banks wanted to boost their growth rate by issuing subprime mortgage lending, along with low interest rates. They ignored the interplay of growth and risk, which led to financial bubbles and it ended with unprecedented losses and bankruptcy of the global economy (Cincinelli, 2017).

On the other hand, there might be a risk that the borrower could either intentionally or accidentally engage in 
activities that are undesirable from the lender's perspective, which means he is less likely to pay back the loan despite the imminent future consequences. The most appropriate answer is that the borrower knows that someone else will have to take the responsibility for the mistake he makes. All of these actions are described as moral hazard and gradually lead to the growth in bad debt ratio.

\subsection{Determinants of Non-Performing Loans}

With the existing finance literature, most of which are based on country-specific studies and researches, it is widely believed that NPLs problem arises as a result of two components, which are macroeconomic and microeconomic factors. For instance, Sinkey and Greenwalt (1991) indicates that both bank-specific (internal) and macroeconomic (external) factors are the main causes of bad debt in the United States. The internal factors are diversified and become specific to a particular bank, individually influencing the level of NPLs. They are most likely to be driven bank's management and performance, while the external factors are out of the control of a bank. They might diverse in level of sector, industry, country or worldwide.

\section{Macroeconomic factors causing NPLs}

Many previous studies have proved that an increase in real GDP adversely affects the financial sector performance, and NPLs in particular. Ranjan and Dhal (2003) examine the coupling of credit risk of public sector banks in India, and found a significant negative relationship between real GDP and NPLs. As explained by Warue (2013) and Dao and Do (2013), a growth in real GDP usually generates more income, which strengthens the debt financing capacity of borrowers, resulting in lower default risk of the debt, and thus, contributes to lower NPLs. On the contrary, when the economy experiences a recession, the level of NPLs should increase. In addition, the same relationship was also identified through the studies conducted by Das and Ghosh (2003), Jimenez and Saurina (2006), Boss et al., (2009), Nkusu (2011), Ekanayake and Azeez (2015) and Ekanayake (2018).

Besides, there are significant empirical evidences concluding that NPLs are highly sensitive to inflation rate. In 2005, based on a granger-causality in a number of Sub-Saharan African countries, Fofack reveals that inflationary pressure is a possible contributor to the high level of impaired loans. Rinaldi and Sanchis-Arellano (2006) analyze the household NPLs in some European countries and stated that NPLs level has a positive relationship with inflation rate. Similarly, Ta et al., (2018) prove that inflation rate moves along with NPLs level in joint-stock commercial banks sector in Vietnam. When inflation rate escalates, government will tighten the fiscal and monetary policies, which weakens the ability to service the debt and increase the probability of default. However, contrary to previous findings, Ekanayake and Azeez (2015) find that inflation of the economy has a strongly negative impact on NPLs of the Sri Lanka commercial banks system.

Interest rates were also identified as a significant contributor for commercial banks' non- performing loans. Berge and Boye (2007) also find that real interest rates have a strong impact on problem loans for the Nordic banking system over the period 1993 - 2005. A decline in real interest rate will lead to a decline in the volume of problem loans. Likewise, Jimenez and Saurina (2006) and Espinoza and Prasad (2010) also ascertain the macroeconomic determinants of NPLs. The empirical evidences support the view that NPLs level worsens since economic growth becomes lower, resulting in the increase in lending interest rates and risk aversion. Furthermore, Dao and Do (2013) explain that the higher prime lending rate will increase the cost of loan charged on borrowers, which forces them to bear higher financial default risk, which in turn increases the NPLs.

Another macroeconomic determinant of NPLs which needs to be considered is the unemployment rate. As to Berge and Boye (2007), NPLs have a significant positive influence from unemployment rate. It indicates that increasing trend in unemployment rate is translated into higher bad debt level. Similarly, Boss et al., (2009) and Nkusu (2011) also provide the same empirical results: there is a positive and significant relationship between unemployment rates spread and NPLs level in Austria. The findings concur with Nkusu's (2011) findings where he concluded that unemployment rates affect the ability to fulfill the debt obligation of borrowers, and thus increasing the level of NPLs.

\section{Bank-specific factors causing NPLs}

Many previous studies have been conducted to identify the relationship between NPLs and some bank-specific factors. For example, in the studies on NPLs in Sub-Saharan Africa, Fofack (2005) emphasizes the relationship of NPLs with economic growth, interbank loans, real exchange rate appreciation, real interest rate, and net interest rate. After that, while investing the roots of bad debt, Louzis et al., (2012) have demonstrated a strong causality between bad debt and return to equity ratio, non-interest income, size, leverage ratio, inefficiency, loan growth and interest expense ratio. The recent study done by N. Ekanayake (2018) concludes that nine variables including ratio of NPLs, ratio of net income, growth in the number of bank branches, ratio of non-interest income, dummy variable for ownership, annual growth in real GDP, prime lending rate, interest rate spread, and annual inflation rate have a relationship with NPLs in Sri Lanka.

There are significant empirical results finding that banks' profitability is a determinant of NPLs. The studies conducted by Aziz et al., (2009), as well as Akter and Roy (2017) about all the impacts on NPLs in general and on bank sector of Dhaka Stock Exchange in particular respectively have identified that there is a sustainable 
relationship between NPLs and bank's profitability. The increase in NPLs will lower the profitability and vice versa. Furthermore, Warue (2013) highlights the significantly negative correlation of NPLs towards return on assets when doing a research on state of NPLs in Kenya. Similarly, Ta et al., (2018) also indicate that profitability in term of ROE has a 10\% adversely impact on NPLs in joint-stock commercial bank sector in Vietnam. However, in a recent research in Sri Lanka context in 2015, Ekanayake and Azeez conclude that bank's profitability is not a significant factor causing NPLs.

Also, empirical literature also gives evidence for banks about the relationship between NPLs and non-interest income. According to DeYoung and Rice (2004), non-interest income is considered when assessing the credit risk. In particular, non-interest income increases bank's profitability, and thus increases the default risk which results in bad debt. Another study done by N. Ekanayake (2018) has the same conclusion that non-interest income is still positive in determining NPLs in Sri Lanka. However, as explained by Dao and Do (2013), high non-interest income will demonstrate that the banks are well-diversified and the overall risk is low; therefore, they have a negative relationship.

The other factor causing NPLs is the bank's size. Warue (2013) identified that there is a significant relationship between them. Dao and Do (2013) found that an increase of $1 \%$ in size will lead to a growth of $0.2125 \%$ in NPLs in bank sector in Vietnam. On the contrary, Ta et al., (2018) state that size has an adverse impact on NPLs. However, this result is not statistically significant. Louzis et al., (2012) explain that increase in size may result in counter-tendencies to the degree of risk-taking. For instance, larger banks may engage in activities that are inherently riskier compared to the activities of smaller banks; therefore, larger size is not likely to lower the credit risk.

The fourth aspect that needs to be considered is leverage ratio. Mentioned by Louzis et al., (2012) when they identify the macroeconomic and bank-specific determinants of NPLs in Greece, the empirical results implied that in leverage tends to increase NPLs, but this effect occurs only to a certain size threshold. After that threshold, leverage does not have any statistically significant effect on NPLs. However, according to Dao and Do (2013), leverage has a positive impact on NPLs in all circumstances when they conduct a quantitative analysis of bad debt in Vietnam.

In addition, there are many statistical evidences about the relationship between NPLs and inefficiency due to bad management. Louzis et al., (2012) ascertain that management inefficiency from previous years sustainably affect the current level of bad deb. In detail, Dao and Do (2013) found that there is a negative relationship between them. On the other hand, Abid et al., (2014) indicate that in most of the models in the studies, inefficiency factor positively influences NPLs, which means that an increase in inefficiency variable leads to an increase in NPLs level.

Concurrently, in the studies done by Louzis et al., (2012), there are also empirical results of banks' risk attitude, as proxied by the solvency ratio. However, they do not find a significant evidence about the relationship between solvency ratio and NPLs with the explanation that the number of banks in Greece is small enough that regulatory authorities can have a precise overview of the riskiness of each bank's loan portfolio and thus easily intervene accordingly. However, applying in a market with large number of banks as Vietnam and the proxy is banks' equity, Ta et al., (2018) indicate that each one unit increase in equity will lead to 0.576 unit increase in NPLs level. They believe that ineffective equity management is the main reason to explain why equity growth can worsen bad debt situation of a bank.

Based on literature evidence, the ownership structure is also an aspect that would affect the level of NPLs of bank sector. When examining the relationship between NPLs and ownership structure of commercial banks in Taiwan et al., (2006) found that the rate of NPLs decreases as government shareholding increases of a bank up to 64 percent and thereafter it increases. However, Warue (2013) indicate that state-owned banks are likely to have a higher NPLs ratio because of the vulnerability to political lobbying and administrative pressure. Meanwhile, Ekanayake (2018) has proved that the ownership structure is not a significant determinant.

Another cause has been demonstrated to have a negative relationship with NPLs is the level of nonperforming loans from previous years. The studies conducted by Blanco and Gimeno (2012) and Louzis et al., (2012) imply that NPLs are likely to decrease when they have increased in the previous quarter. The findings concur with Abid et al., (2014) where they also conclude that the current level of bad debt is adversely influenced by the previous one. In particular, Ta et al., (2018) indicate that when the previous NPLs of a bank increase by one unit, the current NPLs will increase by 30.8 units.

Besides, to be more suitable with the Vietnam's banking sector in particular, Dao and Do (2013) have included two other determinants with the aim to explain the specific features of Vietnam. The two determinants are loan growth and interest expense ratio, both of which have a positive relationship on NPLs. When the interest expense ratio become higher, resulting from higher deposit rate, banks compensate such expenditure by increasing the corresponding lending rates and providing more loans (increase in loan growth rate). This phenomenon will lower the debt servicing capacity of borrowers, thus boost the level of bad debt.

In summary, it is clear that the phenomenon of NPLs is experienced by commercial banks all over the world 
with extensive statistically significant evidences. It can be seen that there are three main literature gaps emanating from these studies when conducting a quantitative analysis about NPLs of listed banking sector in Vietnam.

There is a lack of a proper theoretical model for NPLs. All the reviewed frameworks including Stakeholder theory, Risk Management theory, Adverse Selection theory, and Moral Hazard theory are just most likely to relate to bad debt, but none of them directly explains the causes of NPLs;

Even though there are many international empirical reviews about determinants of NPLs with same explanation direction, external and internal factors, they have given different results on how these factors affect bad debt level;

Studies that did earlier focused on the general banking sector in Vietnam and used a few numbers of banks as a sample and a small duration. There has not been a proper quantitative analysis about bad debt in banking sector in Vietnam's Stock Exchange yet. Moreover, the investigated duration of these studies usually includes the financial crisis year 2008, so it is necessary to test the earlier models in the period after 2008;

These studies are working with former data and their scales are not too big. Besides, although they apply the approach of macro - micro determinants to clarify NPLs, the dataset is not panel data. In addition, these studies' models (e.g., the analyses conducted by Dao and Do (2013) and Ta et al., (2018)) are simple and omit some factors such as unemployment, capital ratio, and ownership structure.

\section{Research methodology}

This research aims to contribute to the gap in this field by covering all 17 listed banks in Vietnam and finding a model to perform the aspect of NPLs.

The conceptual framework is summarized and developed from the research questions and literature review. It indicates the relationship between NPLs in listed banking sector in Vietnam (dependent factors) and the causes including macroeconomic and bank-specific factors (independent factors). It is presented diagrammatically as shown below.
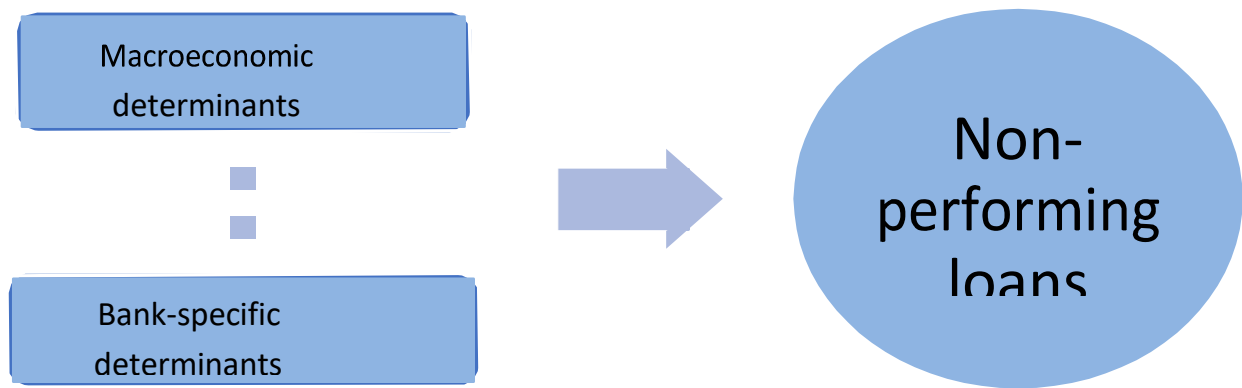

Figure 1: Conceptual framework of NPLs in listed banking sector in Vietnam

\subsection{Population and Sample}

The population for the research is all the commercial banks in Vietnam. According to State Bank of Vietnam, at year-end 2018, there are total 46 commercial banks: 4 state-owned banks, 31 joint- stock banks, 9 wholly foreignowned banks, and 2 joint-venture banks.

The sample for the study includes all 17 listed joint-stock commercial banks on the Vietnam Stock Exchange. Listed banking sector is chosen because of information availability and its significant role in the economy.

The study covered the period from 2009 to 2018 for 17 joint-stock commercial banks. NPLs are presented by two components, macroeconomic and bank-specific factors. There is an aggregated test for the effect on NPLs of each component.

\subsection{Data Collection}

The data has been collected from the annual audited reports of 17 listed banks in the website of Vietstock (https://finance.vietstock.vn/), World Economic Outlook and The World Bank | Data from the period year 2009 2018, after the financial crisis in 2008. The data set consists of two categories, acquired and computed figures. In detail, Gross Domestic Product (GDP) growth rate, Inflation rate, Prime lending rate, Unemployment rate were tracked from World Economic Outlook and The World Bank | Data. Besides, the ratios for computing; Profitability, Non-interest income, Size, Leverage, Inefficiency, Capital ratio, Loan growth rate, Ownership structure and Interest Expense ratio were calculated from the financial statements of the listed banks for period under study. A data collection excel sheet named "Data set" was prepared to assist in gathering the data.

\subsection{Variables}

The variables chosen for the model was guided by three earlier studies. The first study is "Macroeconomic and bank-specific determinants of NPLs in Greece: A comparative study of mortgage, business and consumer loan 
portfolios" conducted by Louzis et al., (2012). The study has proved the relationship between NPLs and NPLs from previous periods, GDP growth rate, Unemployment rate, Inefficiency, Solvency ratio, Return on equity, Size, Noninterest income, Leverage ratio and size, and Ownership concentration.

The second guided study is "Bad debts in Vietnamese banks: Quantitative Analysis and Recommendations" done by Dao and Do (2013). In their model, there are six statistically significant variables, which are NPLs from previous periods, Interest expense ratio, Size, Noninterest income, Return on Equity, and Inefficiency.

The last study, "The Impact of Bank-specific and Macroeconomic Factors on NPLs in Sri Lanka Commercial Banks", conducted by Ekanayake (2018) also pointed out that Return on Assets, Growth in number of bank branches, Non-interest income, GDP growth rate, Prime lending rate of the economy, Interest rate spread, and Annual inflation growth are the factors that affect the level of NPLs.

Table 1: Interpretation of each variable and expected sign

\begin{tabular}{|c|c|c|c|c|c|}
\hline \multicolumn{4}{|c|}{ Macroeconomic factors } & \multirow{2}{*}{$\begin{array}{l}\text { Expected } \\
\text { sign } \\
(-)\end{array}$} & \multirow{2}{*}{$\begin{array}{l}\text { Reference } \\
\text { Louzis et al., } \\
(2012)\end{array}$} \\
\hline 1 & $\begin{array}{l}\text { GDP growth } \\
\text { rate }\end{array}$ & $\mathrm{GDPG}_{\mathrm{t}}$ & $\begin{array}{l}\text { The annual growth in real } \\
\text { GDP in year } \mathrm{t}\end{array}$ & & \\
\hline 2 & Inflation rate & $\mathrm{INF}_{\mathrm{t}}$ & $\begin{array}{l}\text { The annual inflation rate } \\
\text { in year } t\end{array}$ & $(+)$ & $\begin{array}{l}\text { Dao and Do } \\
(2013) \text { and } \\
\text { Ekanayake } \\
(2018)\end{array}$ \\
\hline 3 & $\begin{array}{l}\text { Prime lending } \\
\text { rate }\end{array}$ & $\mathrm{LIR}_{\mathrm{t}}$ & $\begin{array}{l}\text { Prime lending rate in year } \\
\mathrm{t}\end{array}$ & $(+)$ & $\begin{array}{l}\text { Dao and Do } \\
(2013) \text { and } \\
\text { Ekanayake } \\
(2018)\end{array}$ \\
\hline 4 & $\begin{array}{l}\text { Unemployment } \\
\text { rate }\end{array}$ & $\mathrm{UNER}_{\mathrm{t}}$ & $\begin{array}{l}\text { Unemployment rate in } \\
\text { year } t\end{array}$ & $(+)$ & \\
\hline \multicolumn{6}{|c|}{ Bank-specific factors } \\
\hline 5 & Profitability & $\mathrm{ROE}_{i t}=\frac{\text { Profit }_{i t}}{\text { Total Equity }_{\text {it }}}$ & $\begin{array}{l}\text { Ratio of net income to } \\
\text { total asset at bank i at } \\
\text { year } t\end{array}$ & $(-)$ & \\
\hline 6 & $\begin{array}{l}\text { Non-interest } \\
\text { income }\end{array}$ & $\begin{array}{l}\mathrm{NII}_{\text {it }} \\
=\frac{\text { Noninterest income }_{i t}}{\text { Total income }}{ }_{i t}\end{array}$ & $\begin{array}{l}\text { Ratio of non-interest } \\
\text { income to total income of } \\
\text { bank } i \text { at year } t\end{array}$ & $(-)$ & \\
\hline 7 & Banks' size & $\begin{array}{l}\text { SIZE }_{\text {it }} \\
=\log (\text { Total assets })_{\text {it }}\end{array}$ & $\begin{array}{l}\text { Natural logarithm of total } \\
\text { assets of bank } i \text { at year } t\end{array}$ & $(+)$ & $\begin{array}{l}\text { Dao and Do } \\
(2013)\end{array}$ \\
\hline 8 & Leverage ratio & $\mathrm{LR}_{\mathrm{it}}=\frac{\text { Total liabilities }_{\mathrm{it}}}{{\text { Total } \text { assets }_{\mathrm{it}}}}$ & $\begin{array}{l}\text { Ratio of total liabilities to } \\
\text { total asset of bank i at } \\
\text { year } t\end{array}$ & $(+)$ & \\
\hline 9 & Inefficiency & $\begin{array}{l}\mathrm{INEF}_{\text {it }} \\
=\frac{\text { Operating expense }_{\text {it }}}{\text { Operating income }_{\text {it }}}\end{array}$ & $\begin{array}{l}\text { Ratio of operating } \\
\text { expense to operating } \\
\text { income of bank i at year } t\end{array}$ & $(-)$ & $\begin{array}{l}\text { Dao and Do } \\
(2013)\end{array}$ \\
\hline 10 & Capital ratio & $\begin{array}{l}\text { CAPR }_{\text {it }} \\
=\frac{\text { Owned capital }_{\text {it }}}{\text { Total assets }_{\text {it }}}\end{array}$ & $\begin{array}{l}\text { Ratio of owned capital to } \\
\text { total asset of bank i at } \\
\text { year } t\end{array}$ & $(-)$ & \\
\hline 11 & $\begin{array}{l}\text { Ownership } \\
\text { structure }\end{array}$ & STATE $_{\text {it }}$ & $\begin{array}{l}\text { Dummy variable for } \\
\text { ownership where state- } \\
\text { owned banks equal } 1 \\
\text { otherwise } 0\end{array}$ & $(-)$ & \\
\hline 12 & $\begin{array}{l}\text { Non-performing } \\
\text { loans from } \\
\text { previous year }\end{array}$ & NPLs & $\begin{array}{l}\text { Ratio of NPLs to total } \\
\text { loans for bank i at year t-1 }\end{array}$ & $(+)$ & \\
\hline 13 & $\begin{array}{l}\text { Loan growth } \\
\text { rate }\end{array}$ & $\begin{array}{l}\mathrm{LGR}_{\mathrm{it}} \\
=\frac{\operatorname{Loan}_{\mathrm{it}}-\mathrm{Loan}_{\mathrm{it}-1}}{\operatorname{Loan}_{\mathrm{it}-1}}\end{array}$ & $\begin{array}{l}\text { Ratio of the difference } \\
\text { between the outstanding } \\
\text { loans of one year and that } \\
\text { of the previous year to the } \\
\text { previous year outstanding } \\
\text { loan for bank i at time t }\end{array}$ & $(+)$ & \\
\hline
\end{tabular}




\begin{tabular}{|c|c|c|c|c|c|}
\hline \multicolumn{4}{|c|}{ Macroeconomic factors } & \multirow{2}{*}{$\begin{array}{c}\text { Expected } \\
\text { sign } \\
(+)\end{array}$} & \multirow{2}{*}{$\begin{array}{l}\text { Reference } \\
\text { Dao and Do } \\
(2013)\end{array}$} \\
\hline 14 & $\begin{array}{l}\text { Interest expense } \\
\text { ratio }\end{array}$ & $\begin{array}{l}\text { IER }_{\text {it }} \\
=\frac{\text { Interest expense }_{\text {it }}}{\text { Total deposit }_{\text {it }}}\end{array}$ & $\begin{array}{l}\text { Ratio of interest expense } \\
\text { to total deposit of bank } i \\
\text { at year } t\end{array}$ & & \\
\hline
\end{tabular}

\section{Data analysis, results and discussion}

(Source: Louziz, Dao and Do, Ekanayake)

\subsection{Descriptive statistics}

Table 2: Descriptive statistics of all the variables

\begin{tabular}{|c|c|c|c|c|c|c|c|c|c|c|c|c|}
\hline & NPLs & GDPG & INF & LIR & UNER & ROE & NII & LR & INEF & CAPR & LGR & IER \\
\hline Mean & 0.0203 & 0.0610 & 0.0667 & 0.1013 & 0.0301 & 0.1037 & 0.0555 & 0.9133 & 1.0142 & 0.0703 & 0.3469 & 0.0843 \\
\hline Median & 0.0179 & 0.0623 & 0.0565 & 0.0937 & 0.0254 & 0.1054 & 0.0558 & 0.9217 & 0.4842 & 0.0604 & 0.2169 & 0.0715 \\
\hline Maximum & 0.1321 & 0.0681 & 0.1868 & 0.1695 & 0.0460 & 0.2682 & 0.2044 & 0.9594 & 86.302 & 0.2994 & 10.519 & 0.3927 \\
\hline Minimum & 0.0002 & 0.0525 & 0.0088 & 0.0696 & 0.0210 & -0.82 & 0.0027 & 0.7327 & 0.0602 & 0.0262 & -0.30 & 0.0262 \\
\hline Std. Dev. & 0.0148 & 0.0054 & 0.0475 & 0.0327 & 0.0098 & 0.0932 & 0.0390 & 0.0381 & 6.5816 & 0.0384 & 0.8233 & 0.0501 \\
\hline
\end{tabular}

(Source: Results from EViews 10)

Table 2 summarizes the descriptive statistics of 14 variables from 17 listed banks for the years 2009 - 2018. NPL was the dependent variable. Data was obtained using EViews 10. Besides, there are also histogram and density plots for each variable, transferred from $\mathrm{R}$.

NPL, the dependent variable, has a mean of $2.03 \%$. This suggests that banks could not collect $2.03 \%$ of every loan given. The highest NPLs are $13.21 \%$ belonging to SHB in 2011 while the lowest are $0.02 \%$ coming from TPBank in 2011. It follows a highly right-skewed distribution, which means the tail on the right side of the distribution is longer and flatter, and its mean and median is greater than the mode. NPLs also experience a high kurtosis, which may indicate that it has many outliers. NPLs will be more deeply investigated in the part of Discussion of findings.

All the macroeconomic factors have a positive skewness except GDP growth rate, whose mean equals $6.10 \%$. The maximum value is $6.81 \%$ acquired in 2017 , and the minimum value is $5.25 \%$ in 2012 . The skewness of GDP growth rate is -0.37 , between -0.5 and 0.5 , so its data is fairly symmetrical. It also follows platykurtic distribution because the kurtosis is smaller than 3 .

Meanwhile, inflation experiences highly right-skewed data because the skewness is greater than 1 . Inflation rate is also illustrated with leptokurtic distribution (kurtosis $>3$ ). It is because its mean is $6.67 \%$, and it reached the peak at $18.68 \%$ in 2011 when in 2015 , it had the smallest value at $0.88 \%$.

Prime lending rate and unemployment rate has the same type of distribution. In general, they follow the moderately positive skewness as the skewness is between 0.5 and 1 . In term of kurtosis, prime lending rate and unemployment rate all have platykurtic distribution. In particular, prime lending rate's mean equals $10.13 \%$ with the highest value of $16.95 \%$ in 2011 and the lowest value of $6.96 \%$ in 2016 . Unemployment rate experiences a mean of $3.01 \%$ with the highest value of $4.60 \%$ in 2009 and the lowest value of $2.10 \%$ in 2014 .

Besides, there are only two out of seven bank-specific factors having a negative skewness, which are Return on Equity and Leverage ratio. The other variables are Non-interest income, Inefficiency, Capital ratio, Loan growth rate, and Interest expense ratio follow right-skewed distribution. All seven bank-specific factors are presented under leptokurtic distribution, whose tails are fatter and peaks are higher and sharper. Inefficiency and Loan growth rate experience an extremely high kurtosis compared to others, which means that they have a very high volatility.

Specifically, return on equity has a mean of $10.37 \%$. The maximum value equals $26.82 \%$ by ACB in 2011 , while the minimum value is -0.82 by TPBank in 2011 . Noninterest income has a mean of $5.55 \%$. Its highest value is $20.44 \%$ acquired by Techcombank in 2017 , and the lowest value is $0.27 \%$ by Kienlongbank in 2012 . In term of leverage ratio, both BIDV and VietinBank have the highest number of 0.9594 in the same year, 2017, while VPBank has the smallest number of 0.7327 in 2016 . It can be seen that the mean of leverage ratio is 0.9133 , very close with the highest value. The mean of efficiency equals 1.0142. In detail, the lowest value is 0.0602 by Techcombank in 2015, and the highest one as well as the outlier of the data is 86.3019 by TPBank in 2011. Capital ratio has a mean of $7.03 \%$. BIDV and VietinBank one more time together have the smallest value of $2.62 \%$ in 2018 and TPBank has the highest value of $29.94 \%$ in 2012. The mean of loan growth rate equals 0.3469 . TPBank has both the highest and the lowest value of 10.5186 in 2009 and - 0.3010 in 2011 respectively. The last variable is interest expense ratio with the mean of 0.0843. TPBank again has both the highest value of 0.3927 in 2011 and the lowest value of 0.0262 in 2018 . 

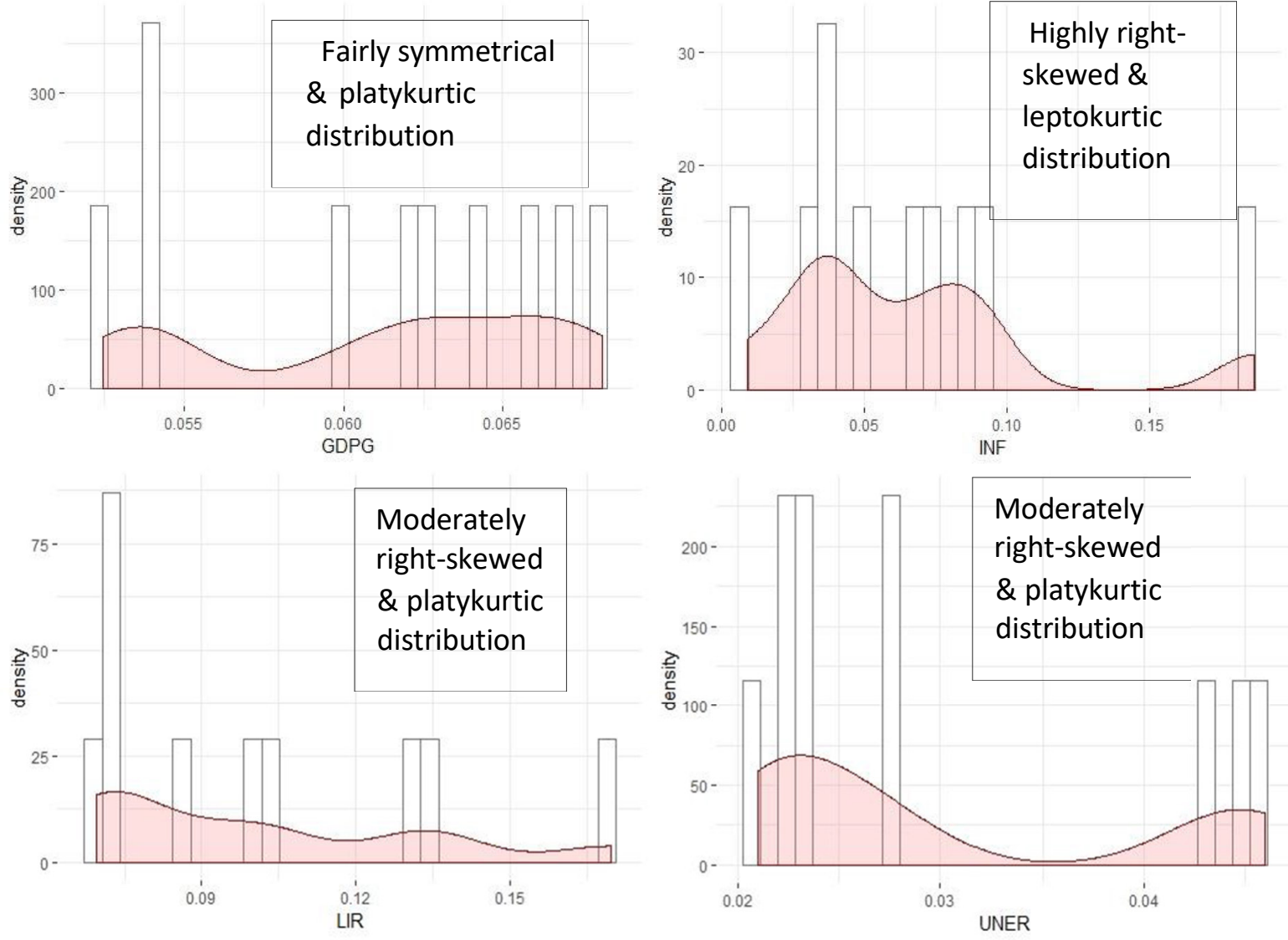

Figure 2: Histogram and density plot of selected variables

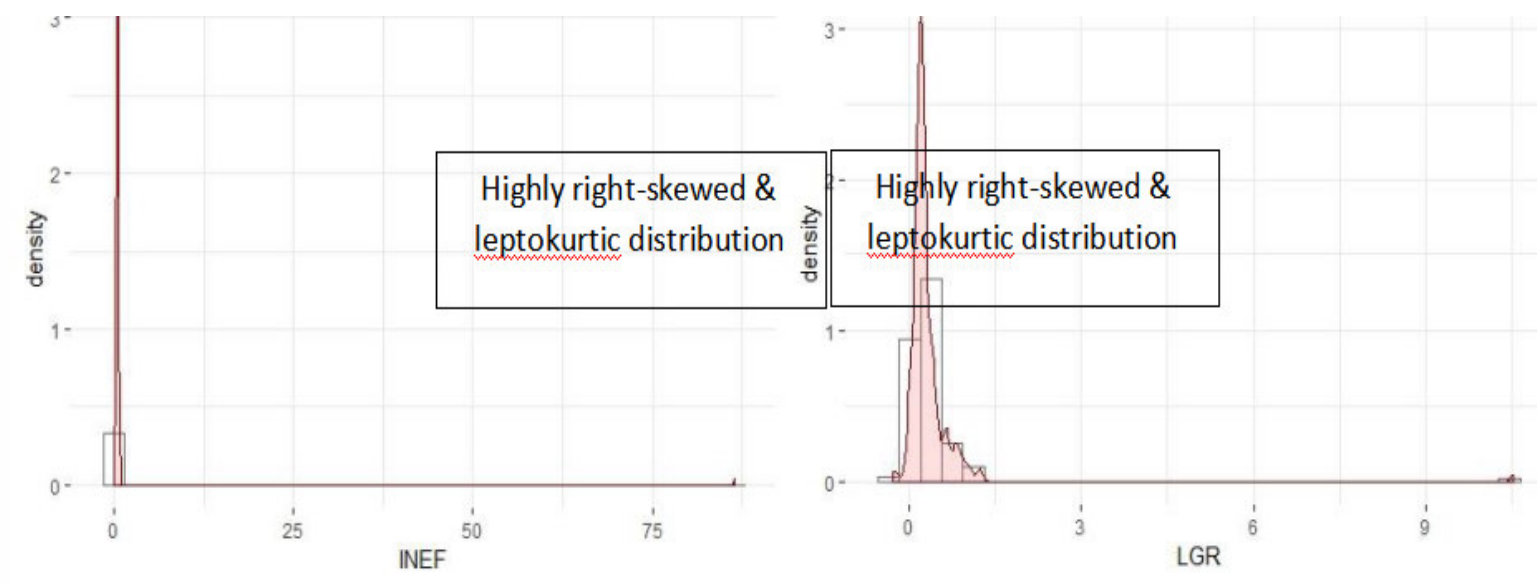

Figure 3: Histogram and density plot of bank-specific factors 


\section{Covariance and correlation Analysis}

The correlation and covariance are presented as follows.

Table 3: Ordinary covariance analysis single table in EViews 10

\begin{tabular}{|c|c|c|c|c|c|c|c|c|c|c|c|}
\hline $\begin{array}{l}\text { Correlation } \\
\text { Probability }\end{array}$ & NPLs & GDPG & INF & LIR & UNER & ROE & NII & LR & INEF & CAPR LGR & IER \\
\hline NPLs & 1.0000 & & & & & & & & & & \\
\hline GDPG & -0.2280 & 1.0000 & & & & & & & & & \\
\hline INF & 0.1388 & -0.2964 & 1.0000 & & & & & & & & \\
\hline LIR & 0.1709 & -0.3795 & 0.9486 & 1.0000 & & & & & & & \\
\hline UNER & -0.0396 & -0.2709 & 0.7476 & 0.7277 & 1.0000 & & & & & & \\
\hline ROE & -0.0825 & 0.0763 & -0.0065 & -0.0253 & 0.1017 & 1.0000 & & & & & \\
\hline NII & -0.0154 & 0.1711 & -0.1621 & -0.2122 & -0.0286 & 0.3367 & 1.0000 & & & & \\
\hline LR & -0.0675 & 0.2288 & -0.1612 & -0.1999 & -0.2000 & 0.0626 & 0.1246 & 1.0000 & & & \\
\hline INEF & -0.0994 & 0.0185 & 0.1907 & 0.1571 & 0.1110 & -0.7734 & -0.0902 & 0.0406 & 1.0000 & & \\
\hline CAPR & 0.0716 & -0.2973 & 0.2303 & 0.2922 & 0.2546 & -0.2842 & -0.3157 & -0.8444 & 0.1023 & 1.0000 & \\
\hline LGR & -0.0790 & -0.1585 & 0.0113 & 0.0093 & 0.2195 & 0.0426 & -0.0481 & -0.1904 & -0.0632 & 0.20901 .0000 & \\
\hline IER & 0.0786 & -0.1624 & 0.7661 & 0.7538 & 0.5178 & -0.3585 & -0.3140 & -0.1872 & 0.4746 & $0.2943-0.0692$ & 1.0000 \\
\hline
\end{tabular}

(Source: Results from Eviews 10)

Correlation is a standardized scale of -1 to +1 , which is utilized to determine the direction of a linear relationship between two variables. As can be seen from the table 3, NPLs has a positive relationship with Inflation rate, Prime lending rate, Capital ratio, and Interest expense ratio. It is negatively related to GDP growth rate, Unemployment rate, Noninterest income, Leverage ratio, Inefficiency, and Loan growth rate. Based on the results, GDP growth rate affects NPLs most, while Noninterest income has the least influence on it.

\subsection{Empirical results}

5.2.1 Initial model

Applying pooled regression model for the initial 14 variables, the initial model will be:

Model 1:

NPLs $=0.02607-0.0165 * \mathrm{GDPG}+0.0774 * \mathrm{INF}+0.1102 * \mathrm{LIR}-0.4246 * \mathrm{UNER}-0.0544 * \mathrm{ROE}$

$+0.04303 * \mathrm{NII}+0.0009 * \mathrm{LOG}(\mathrm{SIZE})-0.0323 * \mathrm{LR}-0.0008 * \mathrm{INEF}-0.0002 * \mathrm{CAPR}$

- $0.0010 *$ STATE $+0.0017 *$ LGR $-0.0016 *$ IER $+0.4468 *$ NPLs $(-1)$

$\begin{array}{ll}\text { R-squared } & 0.389016 \\ \text { Adjusted R-squared } & 0.327032 \\ \text { F-statistic } & 6.276088\end{array}$

It can be seen that although the R-squared and adjusted R-squared is relatively high (38.9\% and $32.7 \%$ relatively), there are only three out of fourteen variables which are significant: ROE, INEF, and NPLs(-1). Fstatistic is very high with low p-value; therefore, there is enough statistic evidence to conclude that at least one parameter is different from zero, which means Model 1 provides a better fit than the intercept-only model. Besides, Durbin-Watson statistic is very close to 2 , so it can be implied that there is no first order autocorrelation in this model.

Meanwhile, the intercept, GDPG, INF, LIR, UNER, NII, LOG(SIZE), LR, CAPR, STATE, LGR,

and IER are not statistically significant due to small p-value. In particular, GDPG, LIR, LR, LGR, IER, and CAPR have the highest $p$-value. It can be explained that the factor such as prime lending rates are not suitable for the context in Vietnam because banks always offer similar interest rates to compete with each other. Likewise, the effect of GDP growth rate and the other bank-specific factors above on the debt-servicing ability and the volume of bad debt respectively can vary greatly among different types of loans. STATE, the dummy one, is kept to see the interaction among variables later.

The next step we used the model to test the redundant variables (mean significant variables), errors testing (heteroskedaticity, multicollinearity, autocorrelation) change of functional forms of variables add interaction among variables, check three models: Pooled, REM, FEM

5.2.2 Hausman test and Redundant Fixed Effects test

$\mathrm{p}$ value for INF, UNER, ROE, LOG(SIZE), INEF, STATE, NPLs(-1), STATE*ROE are 0.0000, 0.0236, 0.0028, $0.0001,0.0007,0.0798,0.0000,0.0127$ respectively.

NPLs $=0.0927 *$ INF $-0.2146 *$ UNER $-0.0352 *$ ROE $+0.0006 *$ LOG(SIZE) $-0.0006 *$ INEF

$-0.0033 *$ STATE $+0.6435 *$ NPLs $(-1)+0.0370 *$ STATE*ROE

$\begin{array}{ll}\text { R-squared } & 0.584865 \\ \text { Adjusted R-squared } & 0.564824 \\ \text { Durbin-Watson stat } & 2.098470\end{array}$

Heteroskedaticity LR Test is the suggested model with the weighted statistics by EViews 10 after the error 
test. It can be seen that both R-squared and adjusted R-squared have increased significantly. In detail, R-squared increased from $38.18 \%$ to $58.49 \%$, while adjusted R-squared soared from $34.74 \%$ up to $56.48 \%$. Durbin-Watson statistic is even closer to 2 , so there is enough evidence to conclude that there is no first autocorrelation.

There are now seven out of eight variables which are significant. In detail, INF has a p-value of 0.00. UNER has a p-value of 0.0236. ROE has a p-value of 0.0028. LOG(SIZE) has a p-value of 0.0001. INEF has a p-value of 0.0007 . NPLs(-1) has a p-value of 0.00. STATE*ROE has a p-value of 0.0127. Although STATE is not significant but its p-value equals 0.0798 , very close to 0.05 , STATE may be considered as a significant variable.

\subsection{Discussion of findings}

\subsubsection{Effect of macroeconomic factors on NPLs}

According to the result from EViews 10, inflation rate (INF) has a significantly positive relationship with NPL in the current year, which is the same as the expectation, $1 \%$ increase in inflation rate leads to $0.09 \%$ increase in NPL. The explanation could be that higher inflation usually means higher interest rates. Although wages may keep pace with inflation, inflation just causes nominal wages to rise. Therefore, borrowers have to pay more interest on the loan, reducing the debt-servicing capacity.

However, the statistical evidence shows that unemployment rate (UNER) has a negative impact on bad debt. $1 \%$ increase in unemployment rate will reduce $0.21 \%$ of NPL. Despite of being opposite with the expected sign, it is understandable that Vietnam has learnt a great lesson after the financial crisis in 2008. Therefore, during recession, to deal with unemployment issue, banks tend to tighten the borrowing policies such as setting stricter requirements for potential borrowers, increasing loan provision and capital adequacy ratio (CAR), so that they can lower the amount of bad debt.

5.3.2 Effect of bank-specific factors on NPLs

It can be seen that NPL from the previous year (NPLs(-1)) is the most significant variable with an extremely small p-value. It also has the biggest influence on NPLs in Vietnam. As demonstrated by the model, $1 \%$ increase in the NPL from previous year results in $0.64 \%$ increase in the NPL of the current year. A possible explanation for this phenomenon is that the high level of bad debt from previous year forces banks to be more cautious when deciding the amount of loans to customers in the current year, thus increasing the ratio of NPLs.

The other significant determinant of NPLs is the size of the banks $(\log (\mathrm{SIZE}))$, whose t-statistic equals 4.004. In particular, banks' size has a positive relationship with NPLs. Every $1 \%$ change in the size will lead to a constant $0.000582 \%$ change in NPL. This result is totally suitable with the findings by Dao and Do (2013), which indicates that the "too-big-to-fail" hypothesis is correct in the context of Vietnam. Although its coefficient is so small, it is undeniable that moral hazard does exist in listed banking system, and the larger banks tend to expose riskier activities.

Meanwhile, return on equity (ROE) is the bank-specific factor which is most negatively related to NPLs. Each $1 \%$ increase in ROE will result in the decrease of $0.035 \%$ in the level on NPL. Bad debt is an expense in Income Statement. A high ROE means that banks have improve expense efficiency, which directly and/or indirectly related to better control over credit risks. It seems that thanks to the good lending procedure, it will not only create a higher profit but also lower the amount of bad debt.

Inefficiency (INEF) is also an important factor which has a negative effect on NPLs, following the above expectation. Again, it emphasizes the important of loan procedure. If banks are more careful in implementing the lending process, although it will face with higher operating expenses, it will lower bad debt level. An increase of $1 \%$ in inefficiency ratio will reduce $0.000588 \%$ of NPL.

Another determinant which negatively affects listed banks' NPL is the ownership structure. In the scope of this research, ownership structure is presented as a dummy variable (STATE). It equals 1 for state-owned banks and 0 for the other cases. Although the statistical evidence is not strong, the p-value (0.0798) is really close to the significant level of 0.05 . Therefore, ownership structure is still considered as an essential factor of NPLs. According to the test result, the state-owned banks have a $0.0033 \%$ decrease in NPLs level compared to non-stateowned banks, which correlates with the earlier literature. In Vietnam, there are only three listed banks that are also state-owned banks, which are BIDV, VietinBank, and Vietcombank. They are not only state- owned but also very big in scale. Hence, it is undeniable that these banks have received a greater support from the State Bank of Vietnam.

The model also employed an interaction term - multiply slope variable by dummy variable, which is STATE*ROE. It is significant to conclude that an increase of $1 \%$ in return on equity of state- owned banks will lead to $0.037 \%$ increase in NPLs level. Even though ROE has a negative relationship with NPLs, when it interacts with the ownership structure, the sign has changed because the size aspect has dominated in this collaboration. State-owned banks are among the largest banks, which are so interconnected with the economic system in Vietnam, and moreover, they belong to State Bank of Vietnam. Thus, these banks are allowed to get involved in riskier financial activities, which increases the amount of bad debt. However, the NPLs level of these banks is always kept under the strict control by SBV to maintain a healthy NPLs ratio. 


\section{Summary, conclusion and recommendations 6.1 Summary of Findings}

This study using panel data methodology attempted to ascertain the effect of macroeconomic and bank-specific factors on the level of NPLs in 17 listed banks in Vietnam's Stock Exchange for the period of 2009 - 2018. The macroeconomic determinants included in the research model were: Inflation rate and Unemployment rate; and bank-specific determinants were: Return on Equity, Banks' size, Inefficiency, and NPLs from previous year.

Applying multi-linear regression for panel data and using EViews and R package for analysis, the pooled effect model was chosen. To understand the relationship among variables, an interaction term between STATE and ROE was added to the model. The new as well as final model has seven out of eight variables which are statistically significant with the adjusted R-squared of $56.48 \%$.

As to the test results, bank-specific determinants contribute to the NPLs level more than macroeconomic determinants. In detail, there are two macroeconomic variables and five bank- specific variables in the final model. Besides, the findings are in agreement with the expectations concluded from earlier studies except for unemployment rate. In particular, Inflation, banks' size, and NPLs from previous year are positively related to NPLs, while unemployment rate, return on equity, inefficiency, and ownership structure have a negative relationship with NPLs.

\subsection{Conclusion and Recommendations}

From the earlier conceptual argument and context of the research, macroeconomic and bank- specific factors do affect the level of NPL. From the findings in the study, it is evident that Multi-linear regression model for panel data is appropriate to identify the determinants of NPLs.

Besides, some recommendations are proposed with the aim at preventing the increase on NPLs in the system and avoid bad debt crisis.

First of all, it is logically to conclude that NPLs from previous year (NPLs(-1)) will significantly contribute to its level in the current year. It implies that banks should solved this problem as quickly as possible before it worsens the situation and leaves severe consequences.

Secondly, unemployment rate is also a big concern for banking system. Although the model in this research has proved that unemployment rate has a negative relationship with NPLs, it does not mean Vietnam should raise unemployment rate to lower the level of NPLs. Instead, it indicates that banks should be more cautious and continue to implement strict lending policy to prevent the bad debt crisis.

The third issue is banks' size because it implies the moral hazard of "too-big-to-fail" that has long existed in the Vietnamese banking system. Therefore, in order to change its, SBV should take action to tighten the control of the operation of big banks such as harsh punishment of regulation violation to prevent the huge losses and set examples for other banks.

Last but not least, cost management, risk management, and lending policies are extremely critical for banks, especially lending policies, to effectively manage bad debts. The results from model recommends that the financial institutions should assign resources so as to improve and complete the credit scoring models, quality of personnel and each components of lending procedure. In addition, Basel II is an optimal proxy for banks in lending process operation, implementation, and supervision.

\subsection{Limitations and Suggestions for Further Research}

It is inevitable that the research has to face with several limitations include: the research did not cover a broad time frame because 170 observations are not the optimal number for multi-linear regression model. Another limitation is that due to the unavailability of the information, quarter data could not be taken in consideration and lower the number of observations, so that it limits the scope of time lag effect. Thirdly, the study tends to oversimplify the situation by not properly investigating the possibility that variables can vary among individuals and time. Hence, the final model can be invalid in some circumstances. Last but not least, the research was guided by 14 initial variables, which cannot conclusively elaborate effects of macroeconomic and bank-specific factors on NPLs. Thus, it may not be enough to estimate the best regression model for NPLs.

For future development of this research, there are various options that can be considered. First of all, a study that covers more variables with longer time span, especially quarter data, than the ones used in this study can give clearer effect of macroeconomic and bank-specific factors on NPLs. Other is that further study can be done addressing the effect of heterogeneity among variables to provide a deeper understanding about NPLs.

\section{References}

Abid, L., Ouertani, M. N., \& Zouari-Ghorbel, S. (2014). Macroeconomic and Bank-Specific Determinants of Household's Non-Performing Loans in Tunisia: a Dynamic Panel Data. Procedia Economics and Finance, 13, 58-68.

Akter, R., \& Roy, J. K. (2017). The impact of non-performing loans on profitability: An empirical study on banking 
sector of Dhaka stock exchange. International Journal of Economics and Finance, 9(3), 126-132.

Auronen, L. (2003). Asymmetric Information: Theory and Applications. Presented at the Seminar of Strategy and International Business, Helsinki.

Aziz, N. F., Ibrahim, I. B., \& Kamaruddin, M. B. (2009). Impact of non-performing loans (NPLs) on profitability performance (ROA, ROE \& NPM). [Online] Available: http://ir.uitm.edu.my/id/eprint/6937/

Berge, O., \& Boye, K. G. (2007). An analysis of bank's problem loans. Norges Bank Economic Bulletin, 65-76.

Blanco, R., \& Gimeno, R. (2012). Determinants of Default Ratios in the Segment of Loans to Households in Spain. Banco De EPANA.

Bofondi, M., \& Gobbi, G. (2003). Bad Loans and Entry in Local Credit Markets. Rome: Bank of Italy, Research Department.

Boss, M., Fenz, G., Pann, J., Puhr, C., Schneider, M., \& Ubl, E. (2009). Modeling Credit Risk through the Austrian Business Cycle: An Update of the OeNB Model (pp. 85-101). OeNB Financial Stability Report, 17.

Cincinelli, D. P. (2017). Non-Performing Loans, Moral Hazard \& Supervisory Authority: The Italian Banking System. Journal of Financial Management, Markets and Institutions, 5-34.

Dao, T. T. B., \& Do, V. A. (2013). Bad Debts in Vietnamese Banks: Quantitative Analysis and Recommendations. Hanoi University, Hanoi, Vietnam.

Das, A., \& Ghosh, S. (2003). Determinants of credit risk in Indian state-owned banks: An empirical investigation. Economic Issues-Stoke and Trent, 12(2), 27-46.

DeYoung, R., \& Rice, T. (2004). Non-interest income and financial performance at U.S. commercial banks. The Financial Review, 39(1), 101-127.

Ekanayake, E. M. N. N., \& Azeez, A. A. (2015). Determinants of non-performing loans in licensed commercial banks: Evidence from Sri Lanka. Asian Economic and Financial Review, 5(6), 868-882.

Ekanayake, N. (2018). The Impact of Bank-Specific and Macroeconomic Factors on Non- performing Loans in Sri Lankan Commercial Banks. Journal of Modern Accounting and Auditing, 14(11), 611-627.

Espinoza, R., \& Prasad, A. (2010). Non-performing loans in GCC banking sector and their macroeconomic effects [International Monetary Fund Working Paper].

Fofack, H. (2005). Non-performing loans in sub-Saharan Africa: Casual analysis and macroeconomic implications (World Bank Policy Research Working Paper No. 3769).

Freeman, R. E. (1984). Strategic Management: A Stakeholder Approach. Boston: Pitman. Holmstrom, B. (1982). Moral Hazard in Teams. The Bell Journal of Economics, 13, 324-340.

Jensen, M. C., \& Meckling, W. H. (1976). Theory of the Firm: Managerial Behavior, Agency Costs and Ownership Structure. Journal of Financial Economics, 305-360.

Jimenez, G., \& Saurina, J. (2006). Credit cycles, credit risk, and prudential regulation. International Journal of Central Banking, 2(2), 65-98.

Kubai, D. K. (2016). The effects of Non-performing loans on Operational efficiency of Commercial banks in Kenya [Research]. University of Nairobi.

Lambert, R. A., Leuz, C. L., \& Verrecchia, R. E. (2011). Information Asymmetry, Information Precision, and the Cost of Capital (No. Working Paper No. 06-21). Wharton Financial Institutions Center.

Loosemore, M., \& Phua, F.T.T. (2010). Stakeholder Engagement in Managing Risk. Australia: University of New South Wales.

Louzis, D., Vouldis, A., \& Metaxas, V. (2012). Macroeconomic and bank-specific determinants of non-performing loans in Greece: A comparative study of mortgage, business and consumer loan portfolios. Journal of Banking \& Finance, 36, 1012-1027.

Nkusu, M. (2011). Nonperforming Loans and Macrofinancial Vulnerabilities in Advanced Economies (International Monetary Fund Working Paper No. 11/161).

Ranjan, R., \& Dhal, S. C. (2003). Non-Performing Loans and Terms of Credit of Public Sector Banks in India: An Empirical Assessment (Reserve Bank of India Occasional Papers No. 3).

Rinaldi, L., \& Sanchis-Arellano, A. (2006). Household Debt Sustainability: What Explains Household Nonperforming Loans? An Empirical analysis. [European Central Bank Working Paper].

Shapiro, A. C., \& Titman, S. (1986). An Integrated approach to corporate risk management. In The Revolution in Corporate Finance. Oxford: Blackwell.

Sinkey, F., \& Greenwalt, M. B. (1991). Loan-loss experience and risk-taking behaviour at large commercial banks. Journal of Financial Services Research, 5, 43-59.

Spikin, I. C. (2013). Risk Management theory: the integrated perspective and its application in the public sector. Netherlands: University of Twente.

$\begin{array}{lllll}\text { State } & \text { Bank } & \text { of } & \text { (2018). Vnline] Available: }\end{array}$ https://www.sbv.gov.vn/webcenter/portal $/ \mathrm{m} / \mathrm{menu} / \mathrm{fm} / \mathrm{htctctd}$ ?centerWidth $=100 \% 25 \&$ left Width $=0 \% 25 \&$ rightWidth $=0 \% 25 \&$ showFooter $=$ false \&showHeader $=$ false \&_adf.ctrlstate $=122$ errobnb_4\&_afrLoop $=13393672402170577$ (April 23, 2019) 
State Bank of Vietnam (2014). Ap dung Basel II: Can co lo trinh phu hop. [Online] Available: https://www.sbv.gov.vn/webcenter/portal/vi/menu/rm/apph/tbnh/tbnh_chitiet?leftWidth=2 $0 \% 25 \&$ showFooter $=$ false \&showHeader $=$ false $\&$ dDocName $=$ CNTHWEBAP01162117558 59\&rightWidth $=0 \% 25 \&$ centerWidth $=80 \% 25 \&$ afrLoop $=13564859547746577 \# \% 40 \% 3 \mathrm{~F}$ afrLoop $\% 3 \mathrm{D} 135$ 64859547746577\%26centerWidth\%3D80\%2525\%26dDocName\%3DC NTHWEBAP0116211755859\%26leftWidth\%3D20\%2525\%26rightWidth\%3D0\%2525\%26showFooter\%3 Dfalse\%26showHeader\%3Dfalse\%26_adf.ctrl-state\%3Dqnmdkgz0_9 (May 20, 2019)

Ta, T. Q. A., Trinh, K. H. T., Le, T. P. L., Tran, H. V., Ton, D. T. L., \& Nguyen, H. V. (2018). Cac yeu to anh huong den no xau ngan hang thuong mai co phan. Olympic Kinh Te Luong va Ung Dung, 2018, 149-156.

Warue, B. N. (2013). The effects of bank-specific and macroeconomic factors on non-performing loans in commercisl banks in Kenya: A comparative panel data analysis. Advances in Management \& Applied Economics, 3(2), 135-164. 